\title{
MORE ON THE VOICING OF ENGLISH OBSTRUENTS: VOICING RETENTION VS. VOICING LOSS
}

\author{
WIKTOR GONET \\ RADOSEAW ŚWIĘCIŃSKI \\ UMCS Lublin
}

\begin{abstract}
In Gonet (2010), one of the present authors found out that English word-final phonologically voiced obstruents in the voicing-favouring environment exhibit asymmetrical, if not erratic, behaviour in that voicing in plosives is most often retained while in fricatives voicing retention concerns only about $1 / 3$ of the cases, with the other possibilities (partial and complete devoicing) occurring in almost equal proportions. The present study is an attempt at exploring the intricacies of devoicing in English to examine to what extent the general tendency towards obstruent devoicing is overridden by voicing retention triggered by adjacent voiced segments both within words and across word boundaries. This study is based on a relatively large knowledge base obtained from recordings of spontaneous R. P. pronunciation.
\end{abstract}

\section{Introduction}

The present study is a follow-up on Gonet (2010), whose focus was on consonantal voicing in the word-final position. The paper presented the behaviour of English obstruents and indicated that the voicing of English word-final obstruents is best described by referring to the combination of word position and the voicing of the initial sound in the following word. These combinations fall into two major classes:

- $\quad$ phonation-favouring (if they are followed by a vowel or a voiced consonant),

- $\quad$ phonation-impeding (before a pause or before a voiceless sound).

The study reviewed a number of publications, including those by Ball and Rahilly (1999), Catford (1964, 1977, 1988), Clark and Yallop (1990), Davenport and Hannahs (1998), Fujimura and Erickson (1999), Gimson (1962, 2001), Gonet (1989, 2001), Gonet and Stadnicka. (2006), Jassem (1983), Ladefoged (1971, 1975), Lisker and Abramson (1964), Maddieson (1999), Ohala. (1999), Port and Rottuno (1979), Raphael et al. (1975), Roach (1983), Shockey (2003), Szpyra-Kozłowska (2003), Van den Berg (1958), and was based on a large body of recordings of spoken English by 6 native speakers. Yet the results exhibited asymmetrical, if not erratic, behaviour; the details are presented in Table 1 as well as Figures 1 and 2. 


\begin{tabular}{|c|c|c|c|}
\hline & BEFORE A PAUSE & $\begin{array}{ll}\text { BEFORE } & \text { A } \\
\text { VOICELESS } & \\
\text { CONSONANT } & \end{array}$ & $\begin{array}{ll}\text { BEFORE } & \text { A } \\
\text { VOICED } & \\
\text { CONSONANT }\end{array}$ \\
\hline PLOSIVES & $\begin{array}{l}\text { Partialy dev. } \\
\text { Completely dev. }\end{array}$ & $\begin{array}{l}\text { Fully voiced } \\
\text { Partially dev }\end{array}$ & Fully voiced \\
\hline FRICATIVES & Completely dev. & Completely dev. & $\begin{array}{l}\text { Fully voiced } \\
\text { Partially dev. } \\
\text { Completely dev. }\end{array}$ \\
\hline
\end{tabular}

Table 1. Voicing in English word-final obstruents (Gonet 2010).

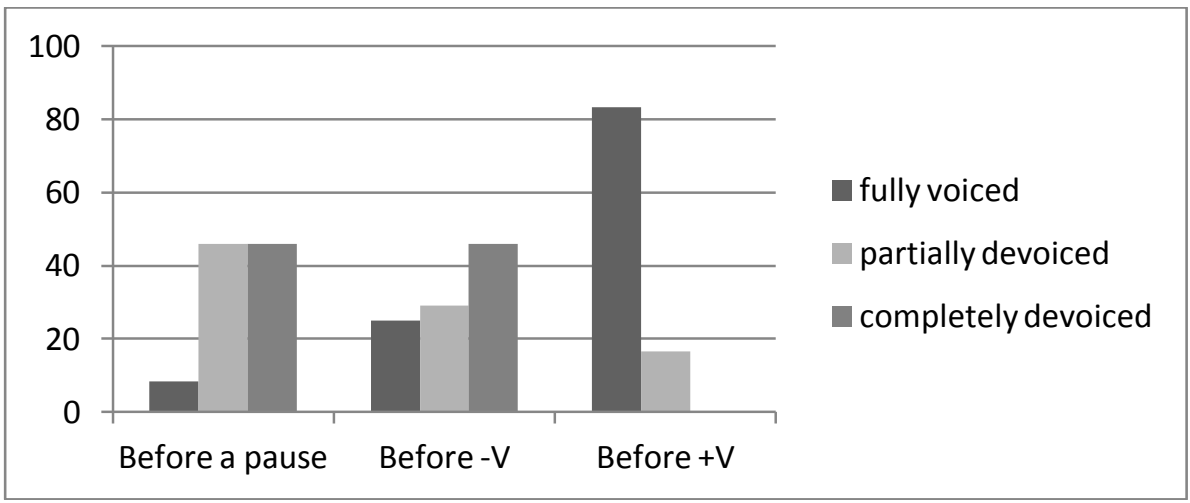

Figure 1 Distribution of voicing in word-final plosives (Gonet 2010).

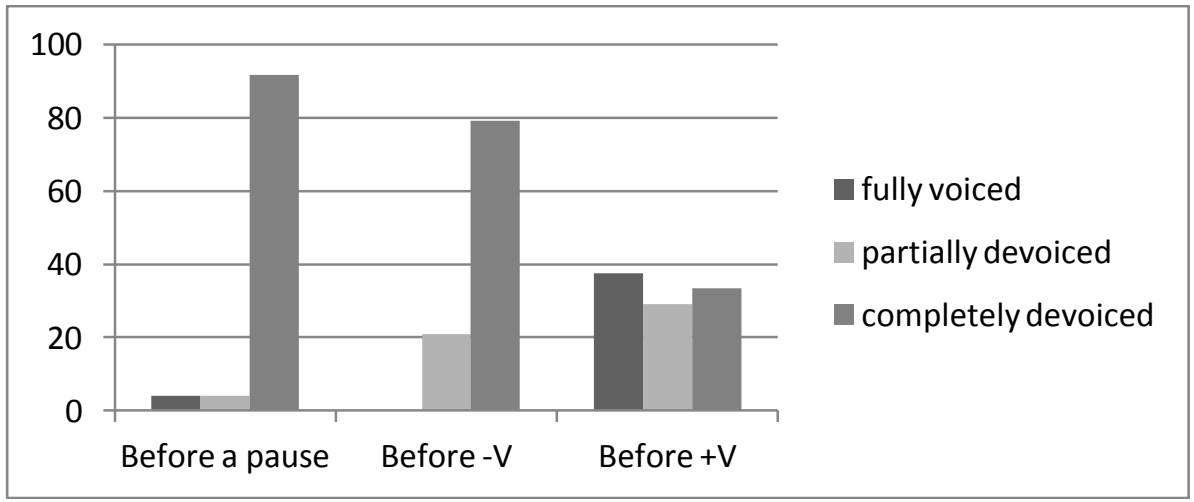

Figure 2 Distribution of voicing in word-final fricatives (Gonet 2010). 
Many authors indicate that obstruents have a natural tendency to devoice, especially in voicing-impeding environments. Hence, for voiced obstruents, hypothetically there apply 2 opposing forces:

- Devoice an obstruent, especially in word-final position

- $\quad$ Retain voicing, especially before a voiced sound

In view of the above, the goal of the present study was to explore the question to what extent the general tendency towards obstruent devoicing is overridden by voicing retention triggered by adjacent voiced sounds both within words and across word boundaries.

\section{Design of the experiment}

As most of the studies on obstruent voicing in English are based on audio material elicited in the form of read wordlists or lexical items embedded in sentence-frames, it appeared imperative that this study should be based on spontaneous speech. For this reason, the authors extracted audio from 4 high definition video recordings of interviews with native speakers of English (2 male, 2 female), whose accent features were characteristic of broadly defined Received Pronunciation.

\subsection{Method}

The audio recordings were then analyzed with a view to extracting sequences of sounds, in which (phonologically) voiced obstruents were flanked by other voiced segments. From each of the recordings, 200 samples were taken out. The selection was not random; the samples were extracted one after another as they appeared in the recording. Thus obtained 800 tokens of obstruents $(\mathrm{X})$ between voiced sounds (V) could generally be classified into three categories (word initial (V\#XV), word medial (VXV), and word

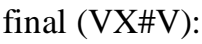

$\mathrm{V \# XV}$

VXV

have go, my business, editors of

VX\#V

editors, about, budding, suggestion

have go, and I, and er, inside of

The waveforms and spectrograms of the samples were then inspected and labelled as either 'fully voiced' or 'devoiced.' The analyzed tokens were assigned to the first category when voicing was maintained throughout the closure and release in the case of stops, and during the entire period of close approximation in spirants. The segments were classified as 'devoiced' whenever there was loss of voicing in the medial phase of the stop and/or VOT was positive, and in the period of close approximation in fricative segments.

Examples of both cases are shown below. Figures 3 and 4 present voicing maintained throughout all stages of the plosive's articulation; a fully voiced fricative is exemplified in Figure 5, whereas Figures 6 and 7 show devoiced obstruents. 


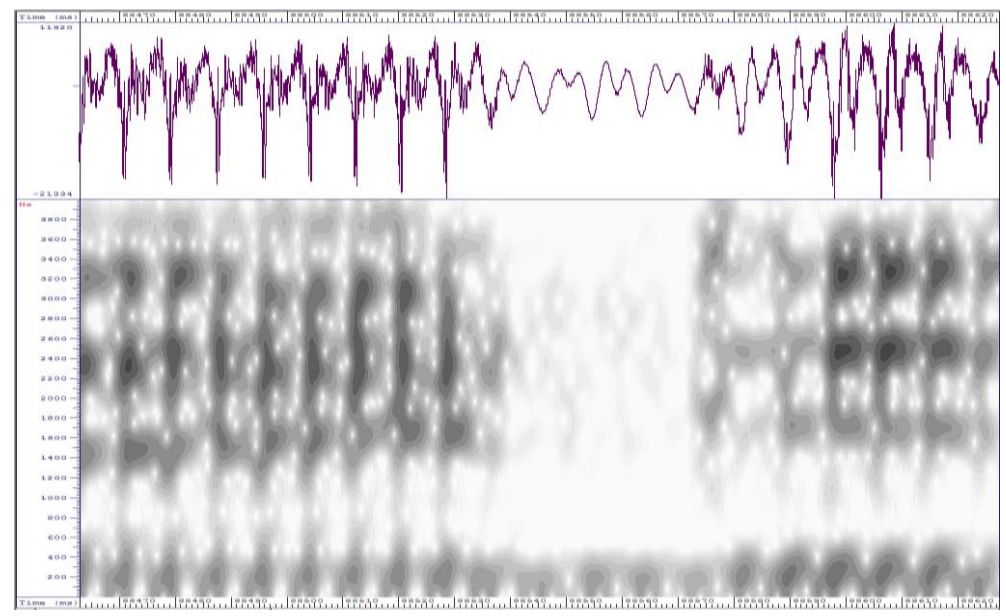

Figure 3 Full voicing of closure in [edi]tors

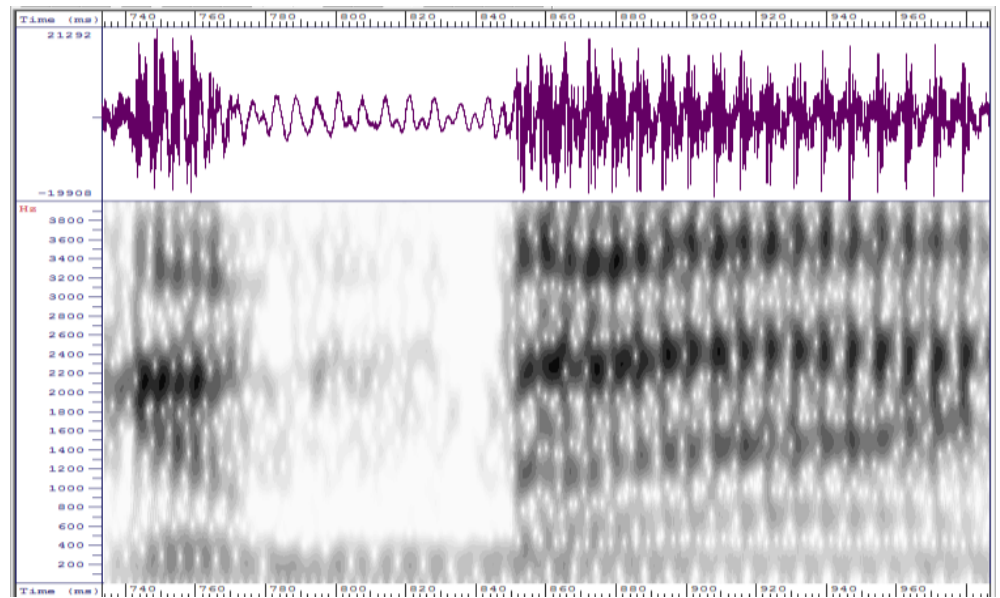

Figure 4 Full voicing in closure in welc[om\#ba]ck 


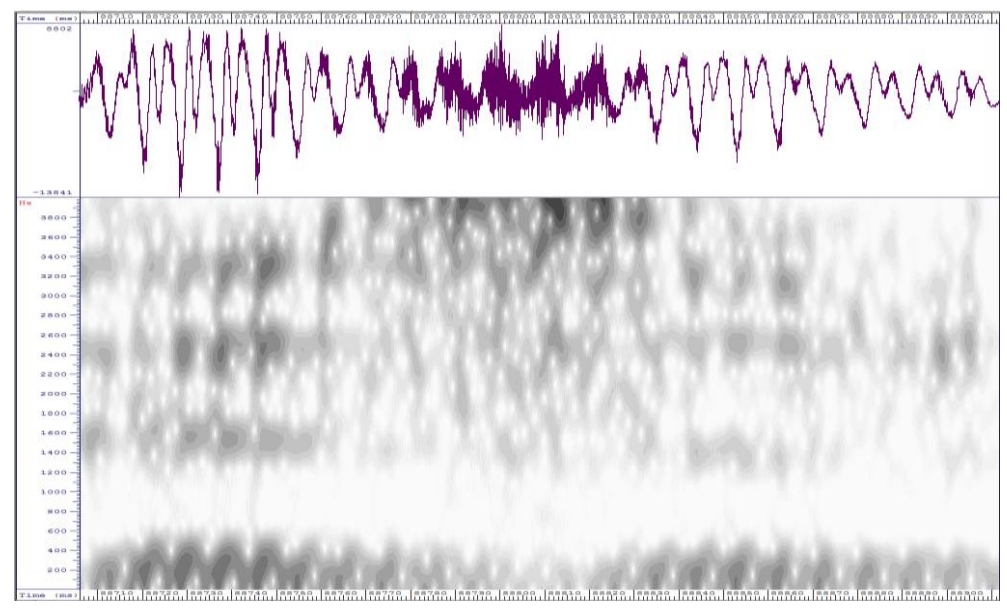

Figure 5 Full voicing od /z/ in edit[əz\#ə]f

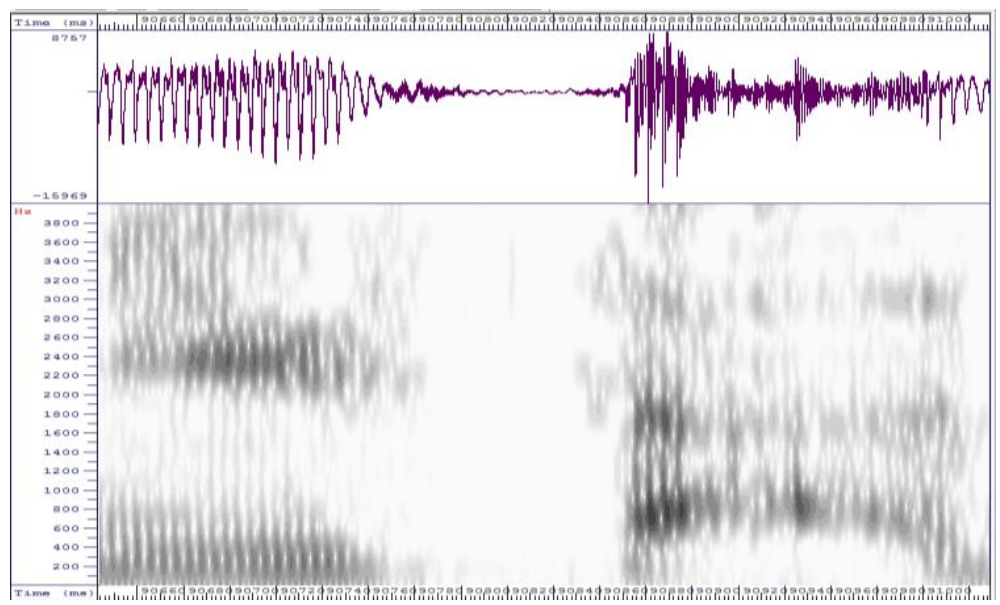

Figure 6 Devoicing of /z/ in $\underline{\mathrm{u}[\mathrm{s} \# \mathbf{X}] \text { at }}$ 


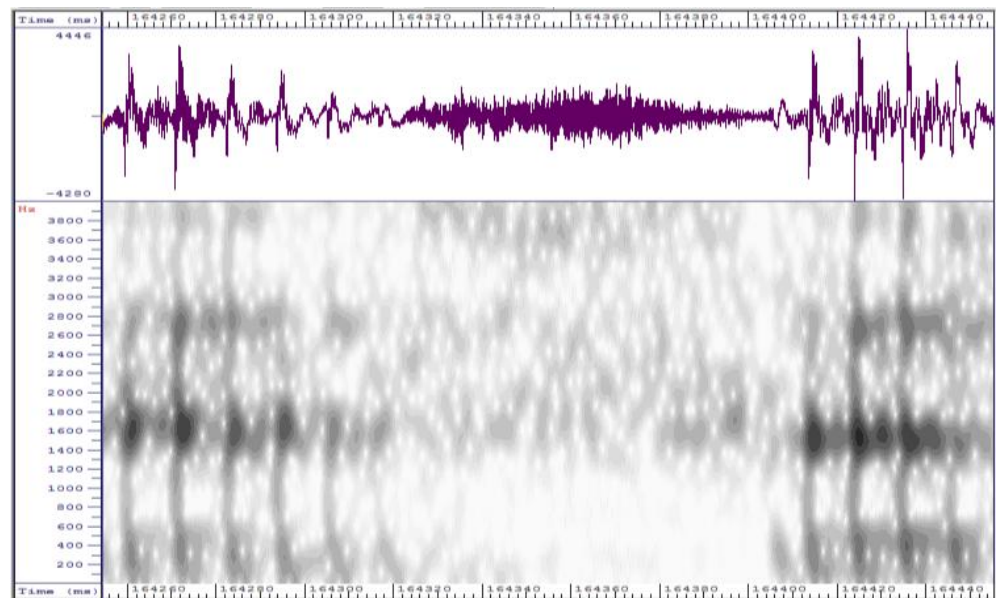

Figure 7 Devoicing of $/ \mathrm{z} /$ in character[s\#ə]f

\subsection{Results}

Overall, 34 per cent of all the tokens were pronounced with voicing loss. The sections below present a detailed analysis of the results, taking into account the following factors:

- phonological category of the examined obstruents

- manner of articulation

- position in the word

- following and preceding context

- stress

- position in the syllable

- lexeme type

If we view the number of devoiced tokens in individual lenis obstruents, it appears that the differences between particular sound categories are more incremental than radical (cf. Fig. 8).

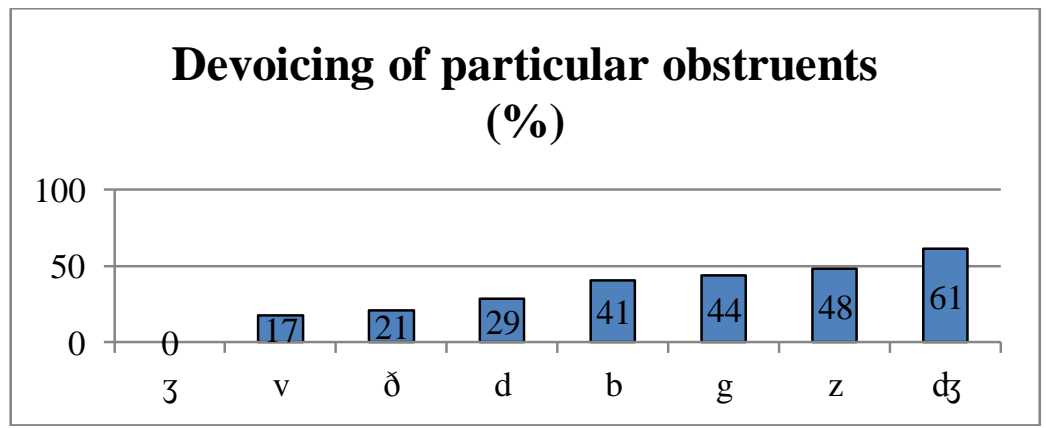

Figure 8 The percentage of devoiced tokens in particular sounds. 
Although the arrangement of sounds in the sequence looks random and does not indicate any relationship with place or manner of articulation, there is a statistically significant difference $(\mathrm{p}<0.001)$ between the affricate which tends to be devoiced in more than $60 \%$ of the cases, and plosives and fricatives, in which devoicing occurs, respectively, in $35 \%$ and $30 \%$ of the cases (Figure 9). Moreover, the results obtained for obstruents containing fricative segments are in line with those presented in Haggard's study (1978) in that there appears a similar progression of devoiced sounds $/ \mathrm{v} /-/ \mathrm{z} /-/ \mathrm{b} /$, with the palatoalveolar affricate becoming devoiced most often, and the labio-dental fricative most frequently retaining its voicing. It should also be noticed that the result for the palatoalveolar fricative $/ 3 /$ should not be regarded as valid for the whole category of lenis palato-alveolar fricatives due to the extremely low frequency of the sound; there occurred only one instance of this consonant in the analyzed material (Asia).

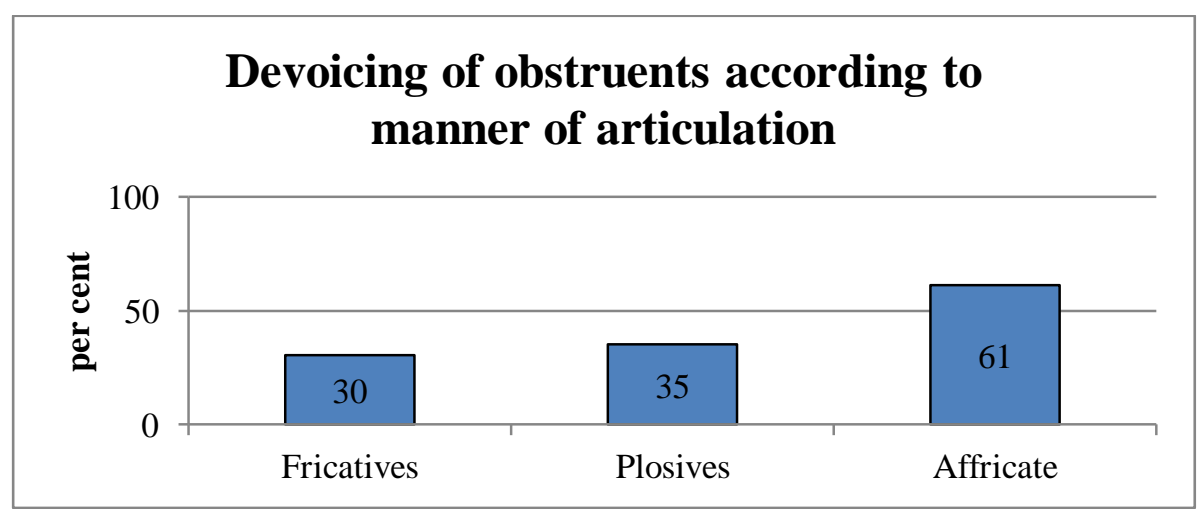

Figure 9 The percentage of devoiced tokens in particular manners of articulation.

In regard to the position in the word, voicing is retained most often word internally (80\%), whereas most devoicing occurs word-initially (44\%, Fig. 10), which shows the relevance of word boundaries in the implementation of voicing as pointed out by Docherty (1992:32). Similarly, in the case of plosives, the results (Fig. 11) match those in Flege and Brown (1982) and Westbury (1979) in that the sounds are least frequently devoiced in word-medial position, namely in $18 \%$ and $3.5 \%$, respectively. The more frequent occurrence of word-medial devoicing in the present study, particularly in comparison to Westbury's result, could stem from the fact that the above mentioned analyses were carried out on elicited disyllabic words, not on spontaneous speech. 


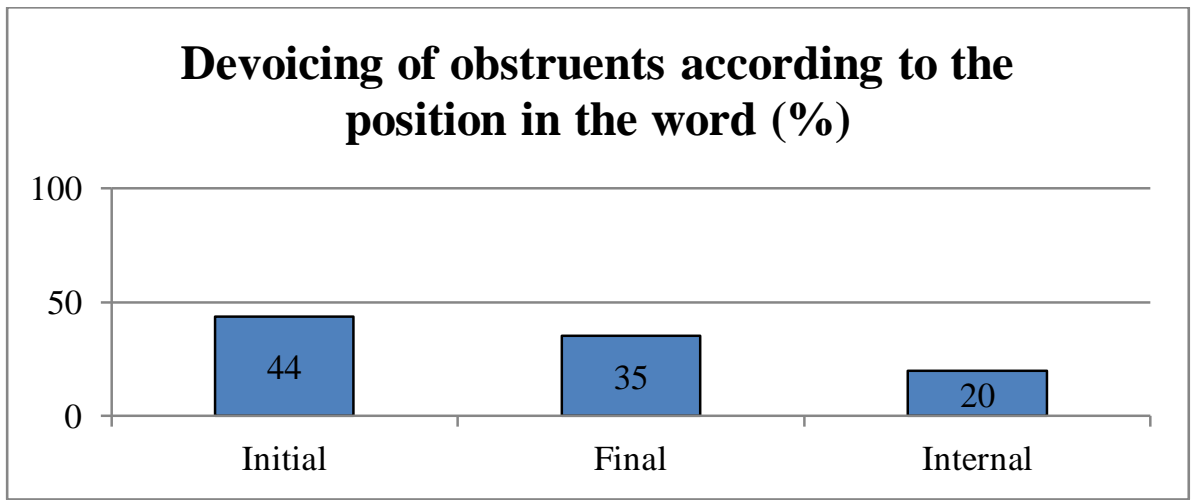

Figure 10 The percentage of devoiced tokens in different word positions.

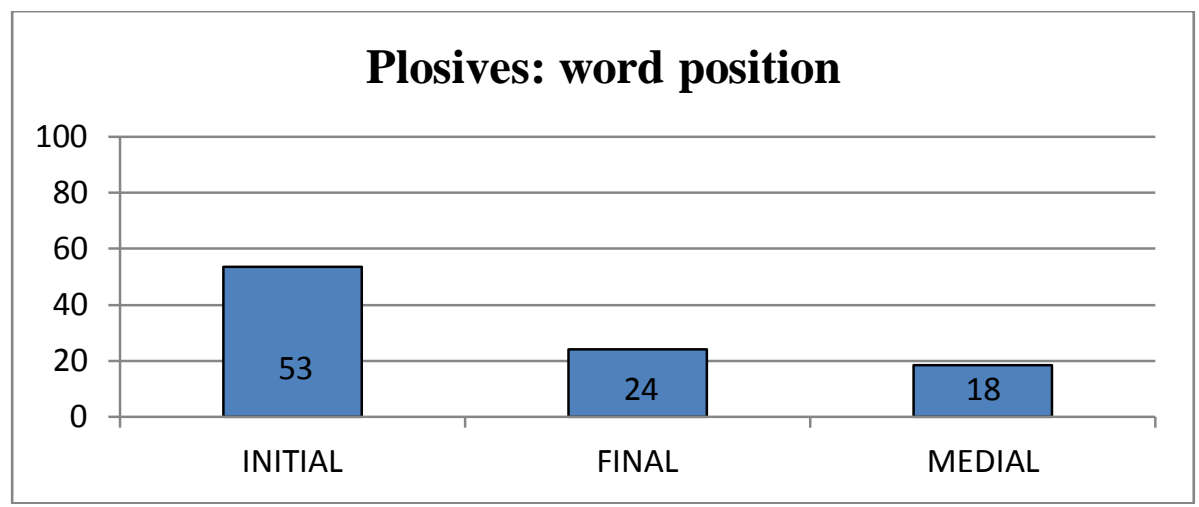

Figure 11 The percentage of devoiced plosives in different word positions.

Regarding the contexts in which obstruents occur, they are most often devoiced in the vicinity of an adjacent obstruent: 59\% in the preceding, and 54\% in the following context. In the context of preceding and following vowels and sonorants, devoicing is less frequent $(\mathrm{p}<0.001$, cf. Figures 12 and 13). An analogous observation was made by Haggard (1978) in a study of words pronounced in isolation, which confirms that the neighbouring sounds are a relevant factor in the realization of voicing. 


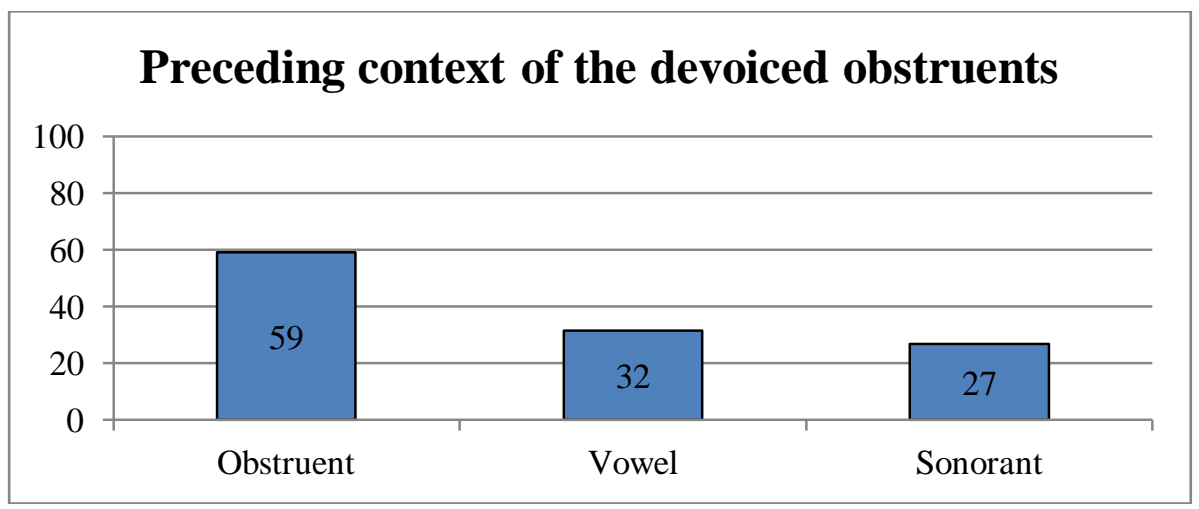

Figure 12 The percentage of devoiced tokens as preceded by specific sound categories.

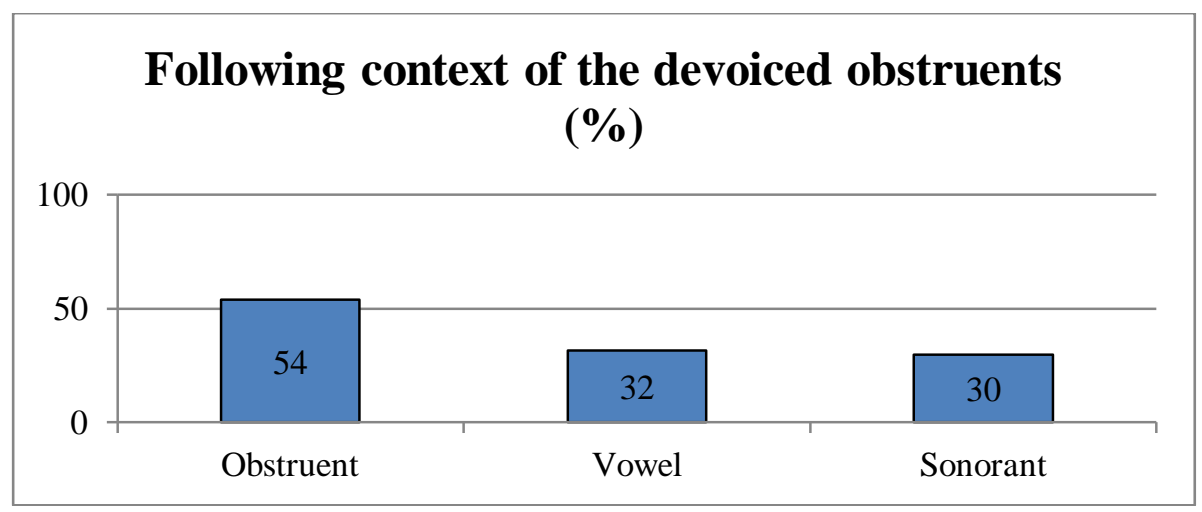

Figure 13 The percentage of devoiced tokens as followed by specific sound categories.

Considering the effect of stress on the voicing of intervocalic lenis obstruents, there is more devoicing $(p<0.001)$ in stressed, than in unstressed, syllables (Fig. 14), while the position in the syllable does not exert a statistically significant effect on the whole (Fig. 15). Assigning word-medial obstruents to syllables was performed according to the Maximal Onset Principle (Goldsmith, 1990:128). 


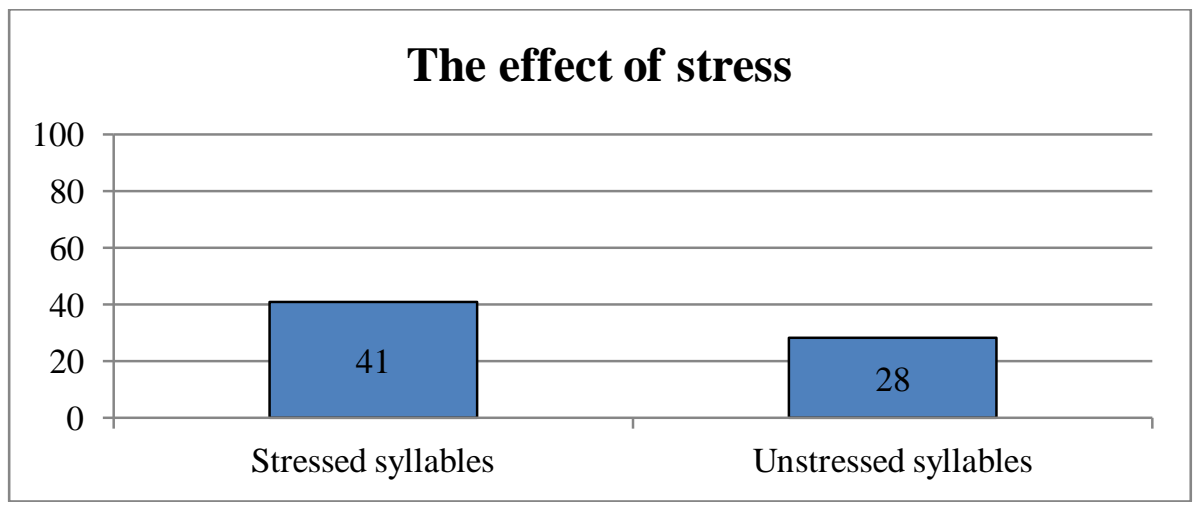

Figure 14 The effect of stress on the percentage of devoiced tokens.

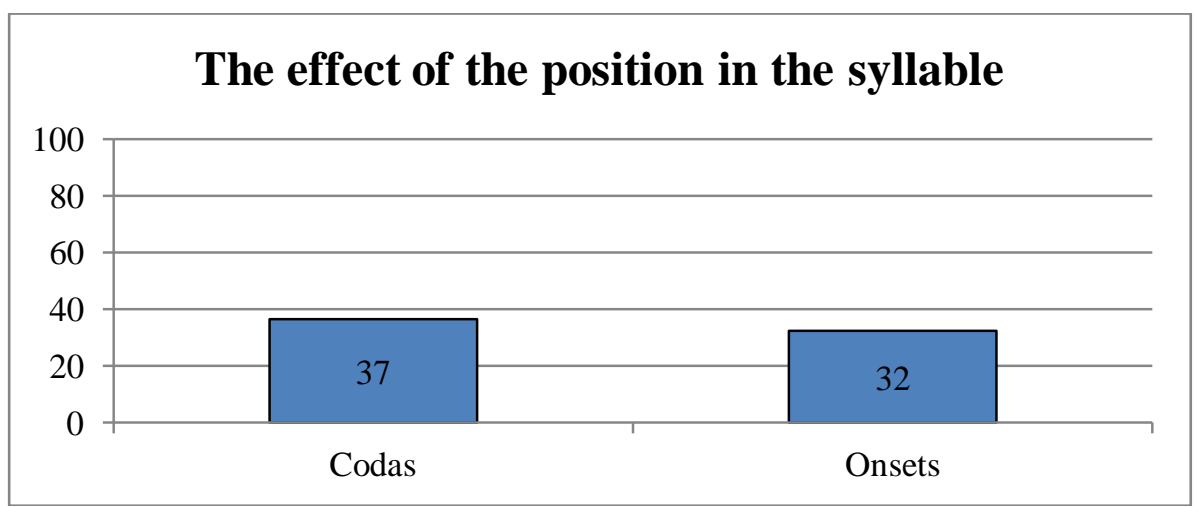

Figure 15 The effect of the position in the syllable on the percentage of devoiced obstruents.

When the interaction of stress and syllable position is taken into account, it appears that the greatest percentage of devoiced obstruents appears in stressed onsets. However, there is a similar amount of devoicing in the opposing environment, i.e. in unstressed codas, while significant differences concern the two previously mentioned contexts vs. stressed codas and vs. unstressed onsets ( $\mathrm{p}=$ between 0.001 to 0.01 , Fig. 16). Thus, it cannot be stated that a particular combination of the position in the syllable and the existence or lack of stress enhance of hinder devoicing. 


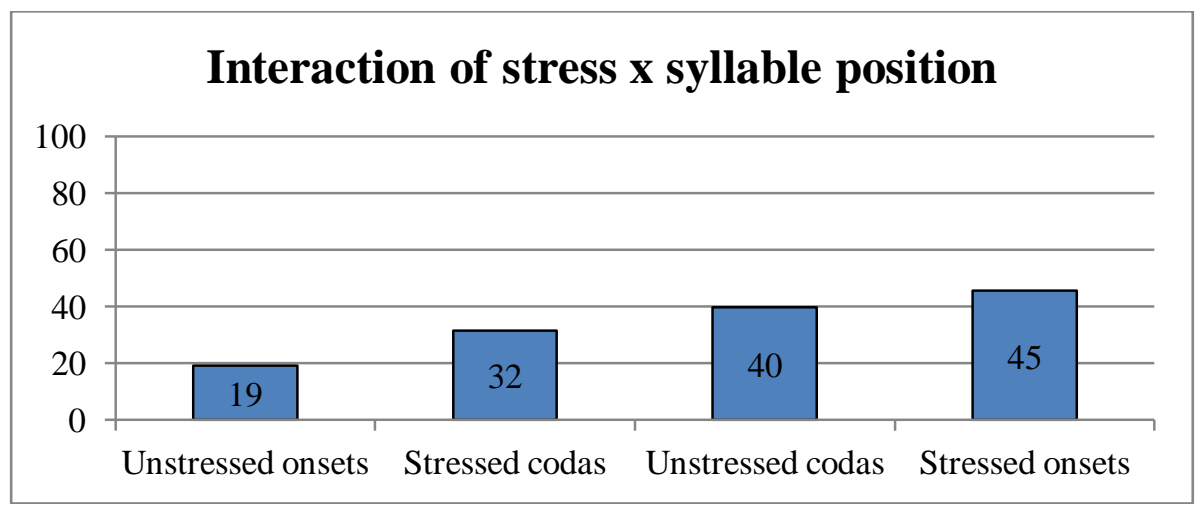

Figure 16 The effect of stress and the position in the syllable on the percentage of devoiced obstruents.

The distinction between function and content words has not found a reflection in the amount of devoicing, and was found in $31 \%$ and $36 \%$ of cases, respectively (Fig. 17).

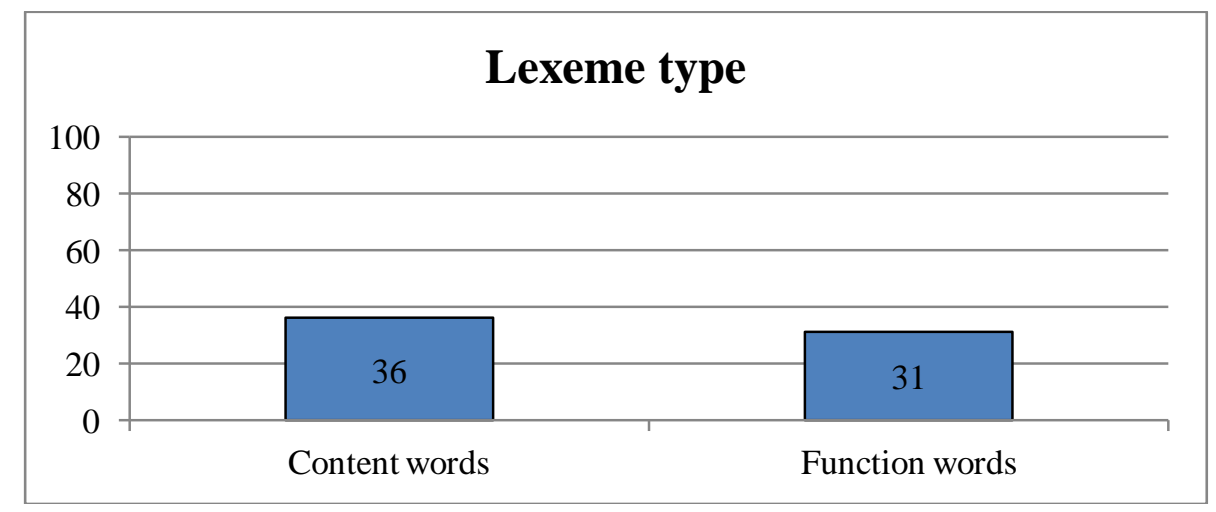

Figure 17 The percentage of devoiced obstruents in content and function words.

Let us now review the effect of stress in each manner of articulation (Figures 18-20). 


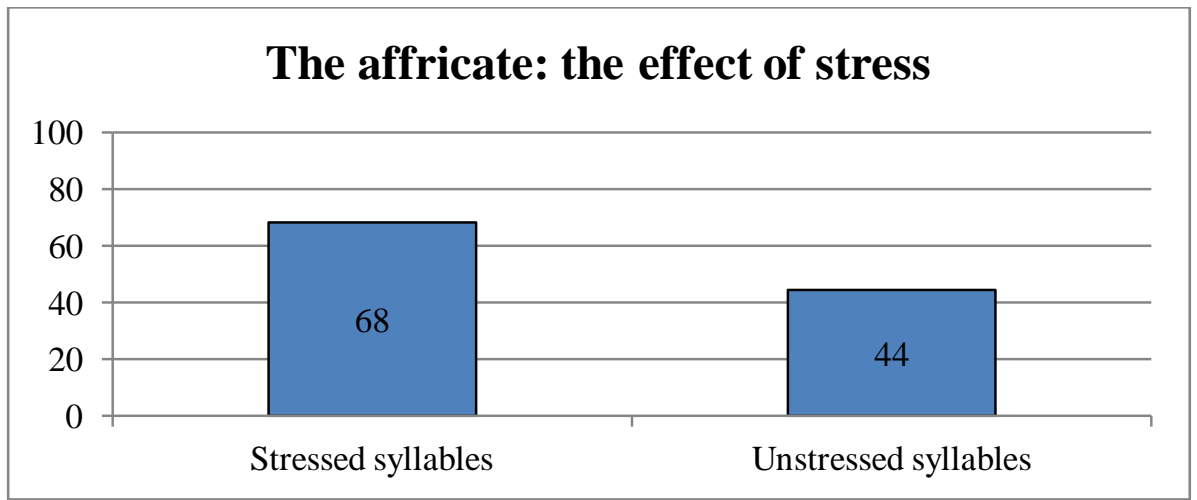

Figure 18 The percentage of devoiced affricates in stressed and unstressed syllables.

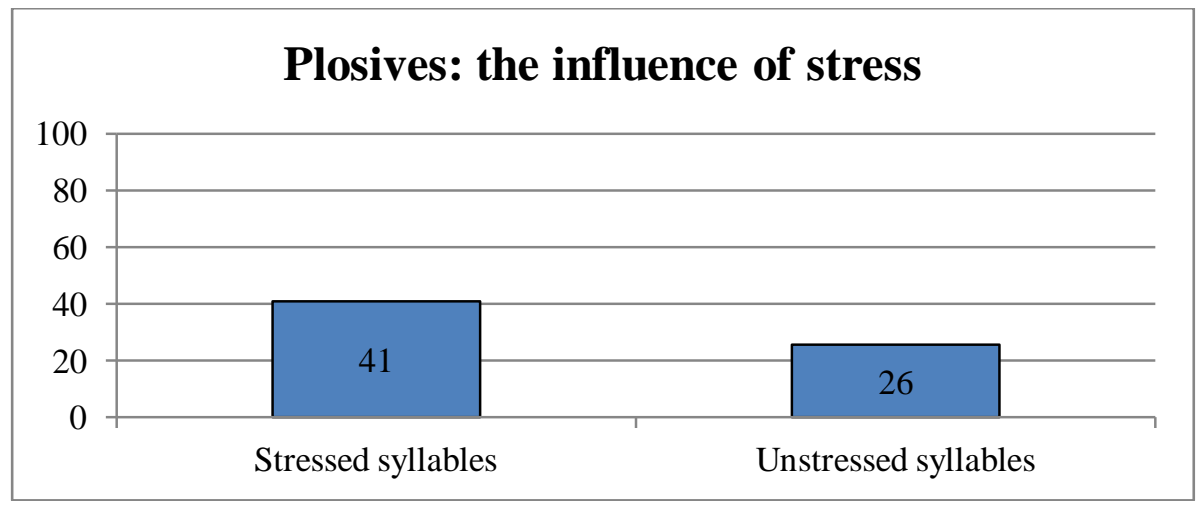

Figure 19 The percentage of devoiced plosives in stressed and unstressed syllables.

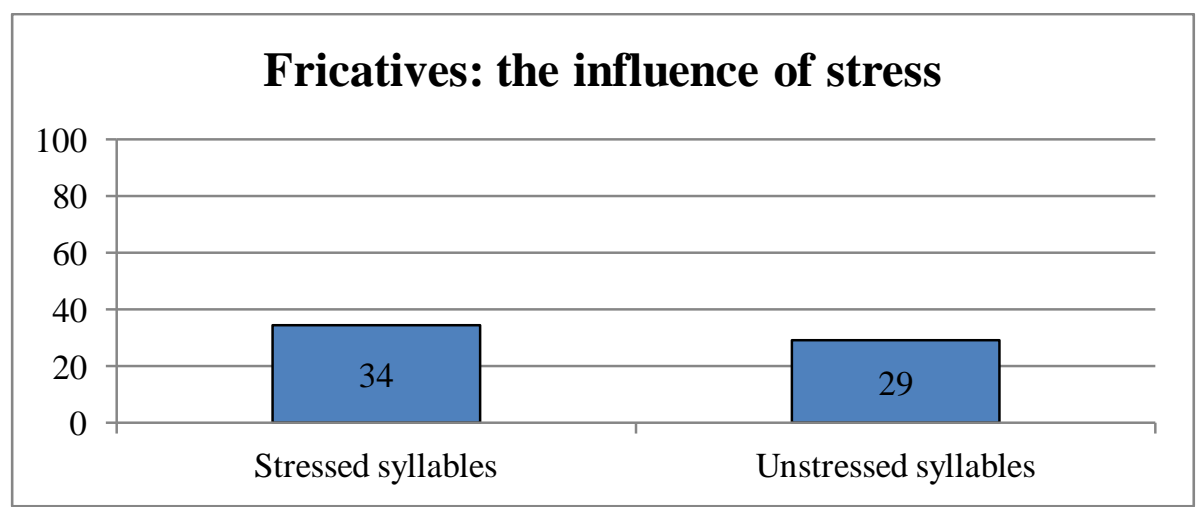

Figure 20 The percentage of devoiced fricatives in stressed and unstressed syllables. 
Significant differences between the amount of devoicing in stressed vs. unstressed syllables were found were found in the affricate (Fig. 18) and in plosives (Fig. 19), while in fricatives the differences were not significant (Fig. 20).

Another comparison was done for the position in the syllable. As was observed in the effect of stress, here, too, the figures for affricates (Fig. 21) are markedly larger than those for fricatives (Fig. 21) and plosives (Fig. 22).

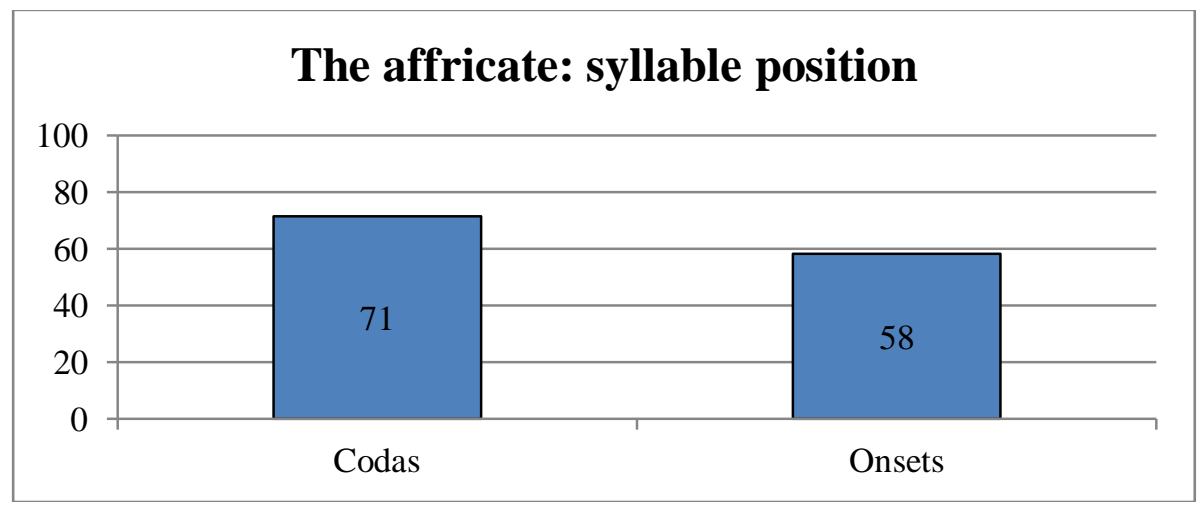

Figure 21 The percentage of devoiced affricates in the onset and coda of the syllable

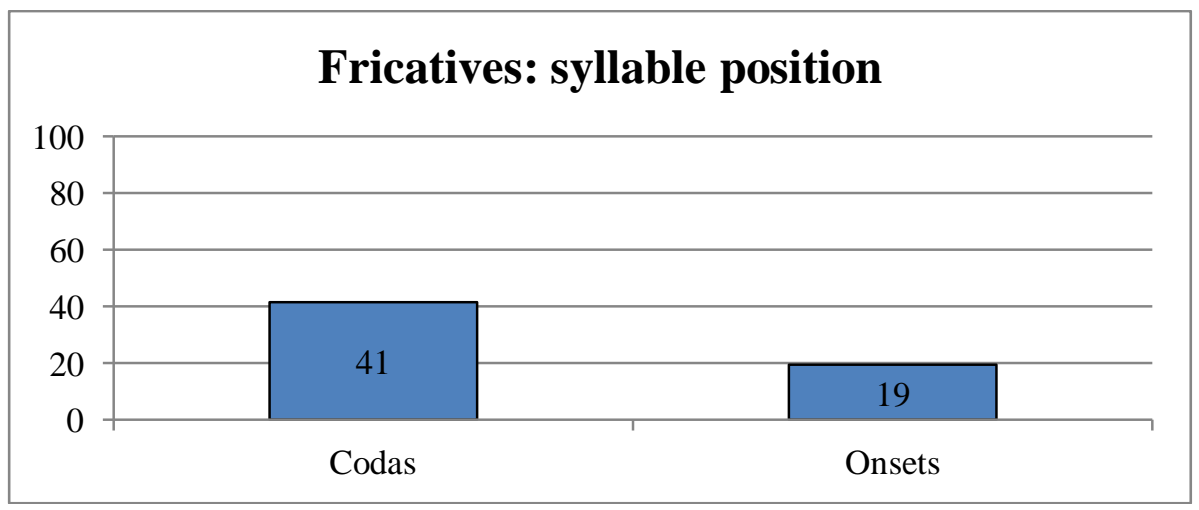

Figure 22 The percentage of devoiced fricatives in the onset and coda of the syllable

The relation of devoicing vs. position in the syllable is reversed in plosives, where more devoicing was noted in onsets than in codas (Fig. 23). 


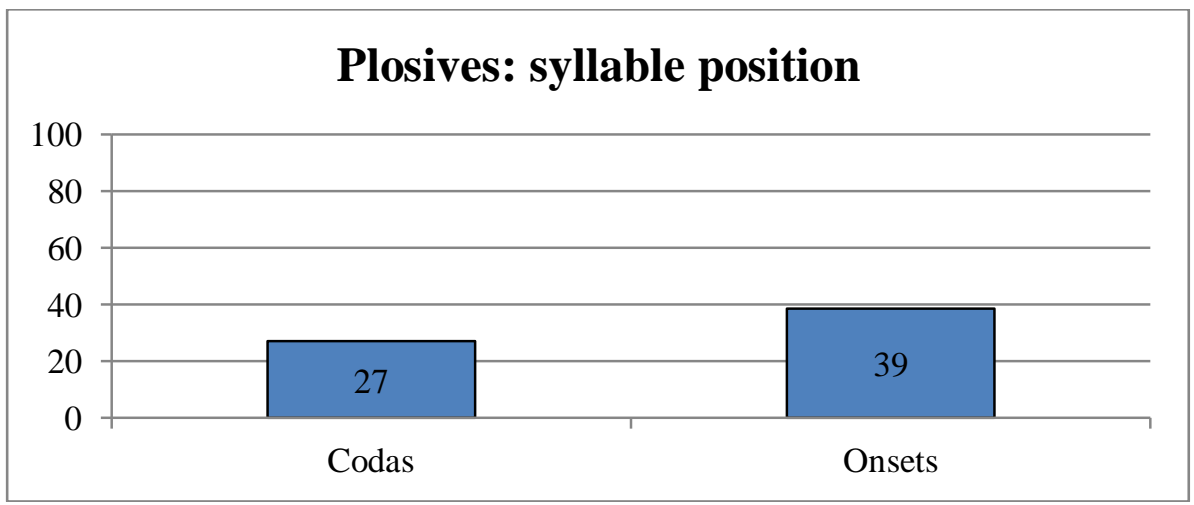

Figure 23 The percentage of devoiced plosives in the onset and coda of the syllable.

Finally, let us observe the interaction of devoicing with the position in the syllable $\mathrm{x}$ stress (cf. Fig. 15 averaged across manner of articulation).

As there appeared no token containing the palato-alveolar affricate in an unstressed coda, Figure 25 shows only three bars for the contexts available in the study.

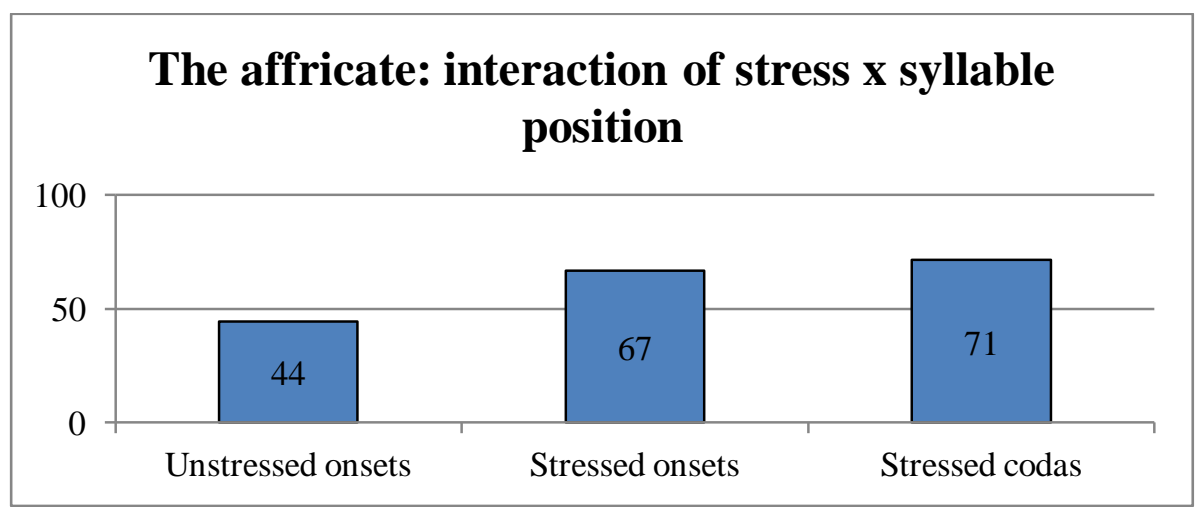

Figure 24 The percentage of devoiced affricates in stressed and unstressed codas and onsets

Thus in the affricate, devoicing is significantly stronger $(\mathrm{p}<0.001)$ when under stress. The results in plosives (Fig. 23) are similar to those in fricatives (Fig. 24), with unstressed onsets and stressed codas favouring devoicing more than the remaining two contexts $(\mathrm{p}<0.001)$. 


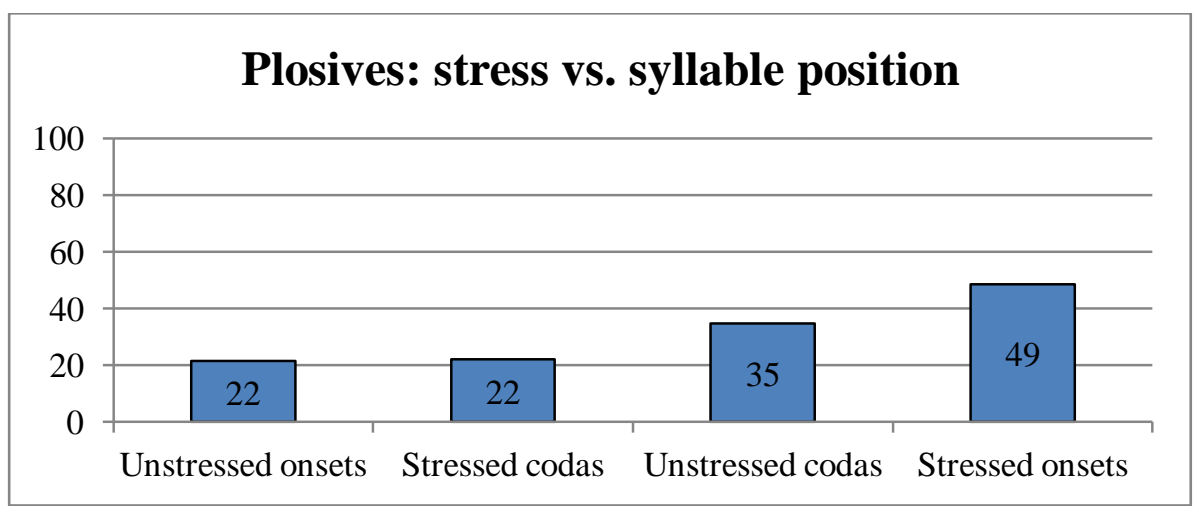

Figure 25 The percentage of devoiced plosives in stressed and unstressed codas and onsets.

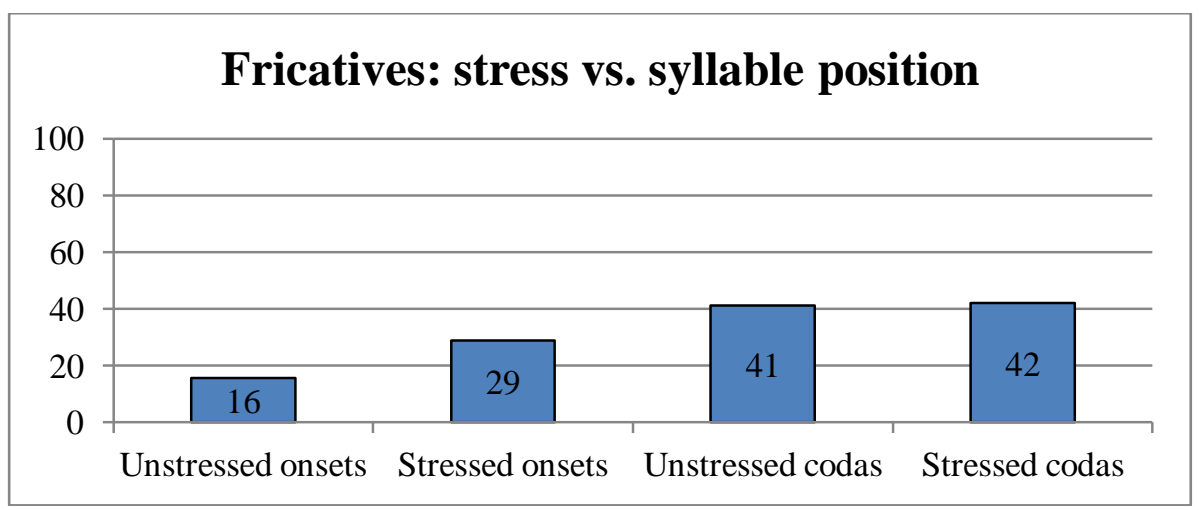

Figure 26 The percentage of devoiced fricatives in stressed and unstressed codas and onsets

\subsection{Conslusions}

Most of the factors considered in the present study appear to affect voicing in intervocalic obstruents. Regarding particular sound categories and manners of articulation, the affricate is devoiced twice as frequently as plosives and fricatives, and of other obstruents, /z/ is most frequently devoiced, probably because its voicing is often predictable morphologically and does not have to be manifested phonetically, while /v/ and /ð/ were devoiced rarely. Plosives are devoiced still less frequently than /z/.

Considering the position of analyzed sounds in the word, it is interesting to see that obstruents devoice more frequently when word-initial than when word-final. This shows that in English the tendency to prolong VOT in stressed syllables exerts a stronger effect than the reduction of Voicing-Into-Constriction. 
Examining voicing in relation to adjacent sounds, it was noted that preceding and following voiced obstruents do not retain voicing as strongly as one would expect; vowels and sonorants exert a stronger voicing-retention effect.

Devoicing is also conditioned suprasegmentally, as most frequently devoicing takes place in stressed syllables.

\section{References}

Ball, M.J. / Joan Rahilly, J. (1999) Phonetics The Science of Speech, London: Arnold

Catford, J. C. (1988) A Practical Introduction to Phonetics, Oxford: Oxford University Press, (2001)

Catford, J.C. (1964) "Phonation types: the classification of some laryngeal components of speech production", (in:) Abercrombie, D. et al. (eds.) In honour of Daniel Jones (p. 26-37), London: Longman

Catford, J.C. (1977) Fundamental Problems in Phonetics, Edinburgh: Edinburgh University Press

Clark, J. / Yallop, C. (1990) An Introduction to Phonetics and Phonology, Oxford: Basil Blackwell

Davenport, M. / Hannahs, S.J. (1998) Introducing Phonetics and Phonology, London: Arnold

Docherty, G.J. 1992. The Timing of Voicing in British English Obstruents. Berlin: Foris Publications.

Flege, J. \& Brown, W., Jr. (1982). The voicing contrast between English /p/ and /b/ as a function of stress and position-in-utterance. Journal of Phonetics, 10, 335-345.

Fujimura, O. / Erickson, D. (1999) "Acoustic phonetics", (in:) Hardcastle, W.J. / Laver, J. (eds.) The Handbook of Phonetic Sciences (p. 65-115), Oxford: Blackwell Publishers

Gimson, A.C. (1962) Gimson's Pronunciation of English, London: Arnold, (2001)

Goldsmith, A. 1990. Auto segmental and Metrical Phonology, Massachusussetts: Basil Blackwell LTD

Gonet, W. (1989) Factorial Analysis of the Duration of R.P. Monophthongs in Monosyllabic Words, diss., Institute of English, Maria Curie-Skłodowska University, Lublin; Acoustic Phonetics Department, Polish Academy of Sciences, Poznań

Gonet, W. (2001) "Obstruent Voicing in English and Polish. Pedagogical Perspective", International Journal of English Studies, 1, nr 1, 73-92

Gonet, W. (2001) Voicing Control in English and Polish: A Pedagogical perspective. International Journal of English Studies. Murcia (Spain): Universidad de Murcia, pp. 73-92.

Gonet, W. 2010. Dispelling the Myth of Word-Final Obstruent Voicing in English: New Facts and Pedagogical Implications. In: E. Waniek-Klimczak (ed.), Issues in Accents of English 2. Cambridge: Cambridge Scholars Publishing pp. 361-376.

Gonet, W. and K. Różańska (2003). Voice Onset Time in Word Initial Lenis Plosives in the Speech of Four BBC Presenters. Speech and Language Technology Vol. 7, pp. 35-52. Poznań: Polish Phonetic Association. 
Gonet, W. and L. Stadnicka. (2006). Vowel Clipping in English. Speech and Language Technology. Vol. 8. Poznań: Polish Phonetic Association.

Haggard, M. (1978). The devoicing of voiced fricatives. Journal of Phonetics 6. 95-102.

Jassem, W. (1983) The Phonology of Modern English, PWN: Warszawa

Ladefoged, P. (1971) Preliminaries to Linguistic Phonetics, Chicago: University of Chicago Press

Ladefoged, P. (1975) A Course in Phonetics, New York: Harcourt Brace Jovanovich

Lipowska, E.B. (1991) Voicing of word final obstruents in R.P. English, M.A. thesis, Maria Curie-Skłodowska University, Lublin

Lisker, L. and Abramson, A.S. (1964) "A cross-language study of voicing in initial stops: Acoustical measurements", (in:) Language and Speech 10, 1-28

Maddieson, I. (1999) "Phonetic universals" (in:) Hardcastle, W.J. / Laver, J. (eds.) The Handbook of Phonetic Sciences (p. 619-639), Oxford: Blackwell Publishers

Ohala, J.J. (1999) "The Relation between Phonetics and Phonology", (in:) Hardcastle, W.J. / Laver, J. (eds.) The Handbook of Phonetic Sciences (p. 674-694), Oxford: Blackwell Publishers

Port, R.F. and Rottuno, R. (1979). "Relation between voice-onset time and vowel duration", (in:) Journal of the Acoustical Society of America, 66, 654-662

Raphael, L.J. et al (1975) "Vowel duration as cues to voicing in word-final stop consonants: spectrographic and perceptual studies", Journal of Speech and Hearing Research, 18, 389-400

Roach, P. (1983) English Phonetics and Phonology. A Practical Course, Cambridge: Cambridge University Press, 1991

Schockey, L. (2003) Sound Patterns of Spoken English, Oxford: Blackwell Publishing

Szpyra-Kozłowska, J. (2003) "The Lingua Franca Core and the Polish learner", (in:) W. Sobkowiak, E. Waniek-Klimczak (eds.) Dydaktyka fonetyki języka obcego. Neofilologia. Zeszyty Naukowe, 5, 193-210, Płock: Państwowa Wyższa Szkoła Zawodowa

Szpyra-Kozłowska, J. et al. (2003) "Priorytety w nauczaniu języka angielskiego", (in:) W. Sobkowiak, E. Waniek-Klimczuk (eds.) Dydaktyka fonetyki języka obcego. Neofilologii. Zeszyty Naukowe, 5, 211-223, Płock: Państwowa Wyższa Szkoła Zawodowa

Van den Berg, J. (1958) "Myoelastic-aerodynamic theory of voice production", Journal of Speech and Hearing Research 3, 1, 227-244

Westbury, John (1979) Aspects of the Temporal Control of Voicing in Consonant Clusters in English, Texas Linguistic Forum 14. Department of Linguistics, University of Texas, Austin. 